NBER WORKING PAPER SERIES

\title{
RELATIVE WAGE VARIATION AND INDUSTRY LOCATION
}

\author{
Andrew B. Bernard \\ Stephen Redding \\ Peter K. Schott \\ Helen Simpson \\ Working Paper 9998 \\ http://www.nber.org/papers/w9998
}

\author{
NATIONAL BUREAU OF ECONOMIC RESEARCH \\ 1050 Massachusetts Avenue \\ Cambridge, MA 02138 \\ September 2003
}

Stephen Redding and Helen Simpson are grateful to the ESRC for financial support for this research under award number RES000220103. This work contains statistical data from ONS that is Crown copyright and reproduced with the permission of the controller of HMSO and Queen's Printer for Scotland. The use of ONS statistical data in this work does not imply the endorsement of the ONS in relation to the interpretation or analysis of the statistical data. Any opinions, results, and errors are the responsibility of the authors. The views expressed herein are those of the authors and are not necessarily those of the National Bureau of Economic Research.

(C2003 by Andrew B. Bernard, Stephen Redding, Peter K. Schott, and Helen Simpson. All rights reserved. Short sections of text, not to exceed two paragraphs, may be quoted without explicit permission provided that full credit, including (C) notice, is given to the source. 
Relative Wage Variation and Industry Location

Andrew B. Bernard, Stephen Redding, Peter K. Schott, and Helen Simpson

NBER Working Paper No. 9998

September 2003

JEL No. F11, F14, C14

\section{ABSTRACT}

Relative wages vary considerably across regions of the United Kingdom, with skill-abundant regions exhibiting lower skill premia than skill-scarce regions. This paper shows that the location of economic activity is correlated with the variation in relative wages. U.K. regions with low skill premia produce different sets of manufacturing industries than regions with high skill premia. Relative wages are also linked to subsequent economic development: over time, increases in the employment share of skill-intensive industries are greater in regions with lower initial skill premia. Both results suggest firms adjust production across and within regions in response to relative wage differences.

Andrew B. Bernard

Tuck School of Business

Dartmouth College

100 Tuck Hall

Hanover, NH 03755

and NBER

andrew.b.bernard@dartmouth.edu

Stephen Redding

London School of Economics

Houghton Street

London, WC2A 2AE

s.j.redding@1se.ac.uk
Peter K. Schott

Yale School of Management

135 Prospect Street

New Haven, CT 06520

and NBER

peter.schott@yale.edu

Helen Simpson

Institute for Fiscal Studies

7 Ridgmount Street

London, WC1E 7AE

hsimpson@ifs.org.uk 


\section{Introduction}

Relative wages vary considerably across regions of the United Kingdom, with skill-abundant regions exhibiting lower skill premia than skill-scarce regions. Adjusted for worker quality, the skill premium in London (in the South East region) is less than 2/3rds that in Northumberland (in the Northern region). This paper shows that this variation in relative wages has important implications for the location of economic activity.

We start by presenting evidence that skill premia vary widely across U.K. regions and that these differences persist over a long time interval. We then report two major results. First, U.K. regions with low skill premia produce different sets of manufacturing industries than regions with high skill premia. Second, relative wages are linked to subsequent economic development: over time, increases in the employment share of skill-intensive industries as well as in the skill-intensity of production are greater in regions with lower initial skill premia. Both responses suggest firms adjust production across and within regions in response to wage differences.

The existence of relative wage variation within the U.K. is consistent with the general equilibrium Heckscher-Ohlin model, which has the relative wages and product mix of sufficiently disparate regions varying with relative factor endowments. In equilibrium, regions that are abundant in skilled workers offer low skill premia. As a result, skill-abundant regions are attractive locations for skill-intensive industries. The purpose of this paper is to test the strength of this attraction. U.K. relative wage variation is inconsistent with standard multiple factor economic geography models that predict a positive relationship between skill premia and skill abundance as a result of agglomeration externalities.

Our estimates of relative wage differences exploit a new methodology introduced by Bernard and Schott (2003) that controls for unobserved variation in factor quality and production technology across geographic areas. We confirm earlier research by Bernard et. al (2003) that uncovers significant differences in skill premia and production patterns across U.K. regions. $^{1}$ In this paper we examine the structure of U.K. wages and pro-

\footnotetext{
${ }^{1}$ Other research on earnings variation in the UK includes Cameron and Muellbauer (2000,2001), Duranton and Monastiriotis (2002), HM Treasury (2001), Jackman and Savouri (1991), and Venables and Rice (2003).
} 
duction across a longer time interval and find no convergence of skill premia from the 1970s to the 1990s. We also present new evidence on the dynamic response of industries to persistent variation in regional skill premia.

Using data on regions within a country allows us to investigate the link between wage variation and industrial structure while controlling for many of the unobservables present in comparable cross-country analyses. These unobservables include differences in how workers are educated and trained as well as how goods are produced. Our U.K. data tracks production of 209 four-digit manufacturing industries across 63 counties and Scottish Regions over two decades. These data provide far greater resolution of economic activity than traditionally-used datasets. ${ }^{2}$

Understanding the relationship between relative wages and industrial structure is critical for a wide range of public policy debates. ${ }^{3}$ One interpretation of our results is that industries move towards workers more readily than workers move towards industries. As a result, regional development assistance designed to introduce new, skill-intensive industries to faltering, skill-scarce regions may be less successful than policies designed to boost skill-scarce regions' skilled labor pools.

The paper is structured as follows. Section 2 tests for relative wage equality across U.K. regions and examines the link between industrial structure and relative wages. Section 3 how industries have responded to initial differences in relative wages across regions. Section 4 concludes.

\section{Production Structure and Relative Wages}

The general equilibrium Heckscher-Ohlin model sets up a systematic relationship between regional production structure and relative factor prices. Figure 1 illustrates the producer equilibrium graphically using a Lerner (1952) diagram.

For simplicity, we consider an example with two factors of production (skilled labor, $N$, and unskilled labor, $P$ ) and three industries (relatively high skill Computers, relatively low-skill Textiles, and intermediate Machinery). The same arguments apply with arbitrary numbers of industries

\footnotetext{
${ }^{2}$ Existing U.K. research largely focuses on the 10 Administrative Regions of Great Britain and substantially more aggregate industrial classifications.

${ }^{3}$ See, for example, Cabinet Office (1999) and HM Treasury (2001).
} 
and factors of production (Leamer 1987). The endowments of skilled and unskilled labor of regions $A$ and $B$ are respectively $E_{A}$ and $E_{B}$. Production technologies are characterized by the industries' unit value isoquants and, for simplicity and without loss of generality, the figure is drawn for the case of Leontief or fixed unit input requirement technologies. The analysis is directly analogous for technologies with unit input requirements that vary with relative factor prices.

Even if regions face common commodity prices and have identical technologies, sufficiently large differences in endowments induce specialization in different mixes of industries with different equilibrium relative factor prices. Skill-abundant region $A$ produces skill-intensive Computers and Machinery, while skill-scarce region $B$ specializes in Machinery and Textiles. Each region lies within a different cone of diversification, where the word 'cone' refers to the set of endowment vectors that select the same set of industries. In the equilibrium depicted in the figure, there is an overlap of regional product mix because both regions produce the moderately skill-intenisve Machinery. If production technologies were characterized by variable unit input requirements (not shown in the figure), this overlap industry would be produced more skill intensively in $A$ and less skill intensively in $B$.

The relative wage of skilled workers is lower in the skill-abundant abundant region so that, as one looks across regions in different cones of diversification, the relative wage of skilled workers falls discretely with regional skill-abundance. Thus, differences in relative factor prices are associated with systematic differences in production structure across regions. This is a general equilibrium relationship between two endogenous variables, which we examine further in the empirical analysis below.

\subsection{Relative Wages and Relative Wage Bills}

The theory described in the previous section focuses on the price paid to identical workers in each region. In practice, both the quality and composition of workers may vary substantially across regions even within skill categories. ${ }^{4}$ In this section, we briefly review an empirical methodology for

\footnotetext{
${ }^{4}$ There is a long tradition in the international trade literature emphasizing this idea, see in particular Leontief (1953) and Trefler (1993).
} 
testing relative wage differences, introduced by Bernard and Schott (2003), that is robust to unobserved variation in factor quality and composition.

Assuming that the production technology is constant returns to scale in quality-adjusted skilled workers $(N)$, unskilled workers $(P)$ and capital $(K)$, and assuming that firms minimize costs, the relative demand for observed quantities of skilled workers $(\widetilde{N})$ and unskilled workers $(\widetilde{P})$ is:

$$
\frac{\widetilde{N}_{r j}}{\widetilde{P}_{r j}}=\frac{\theta_{r j}^{P}}{\theta_{r j}^{N}} \frac{\partial B_{r j} / \partial w_{r}^{N}}{\partial B_{r j} / \partial w_{r}^{P}}
$$

where $\theta_{r j}^{z}$ is the unobserved quality of factor $z$ in industry $j$ of region $r$; $B_{r j}=A_{r j} \Gamma_{j}\left(w_{r}^{N}, w_{r}^{P}, w_{r}^{K}\right)$ is the unit cost function; $w_{r}^{z}$ denotes the price of quality-adjusted factor $z$ in region $r$; and $A_{r j}$ is a Hicks-neutral regionindustry technology difference.

Under the null hypothesis that quality-adjusted relative wages are the same across regions, observed relative wages vary solely because of unobserved differences in factor quality:

$$
\frac{\widetilde{w}_{r}^{N}}{\widetilde{w}_{r}^{P}}=\frac{\theta_{r j}^{N}}{\theta_{r j}^{P}} \frac{\widetilde{w}_{s}^{N}}{\widetilde{w}_{s}^{P}}
$$

where a tilde $(\sim)$ above a variable again denotes an observed value and where, without loss of generality, we have chosen region $s$ as the benchmark for measuring factor quality $\left(\theta_{s j}^{z}=1\right)$.

Multiplying observed relative wages and observed relative employments in equations (1) and (2), the terms in unobserved factor quality cancel. Under the null hypothesis that quality-adjusted relative wages are equalized across regions, relative unit factor input requirements are the same, and we obtain the prediction that observed relative wage bills are equalized across regions:

$$
\frac{{\widetilde{\text { wagebill }_{r j}}}^{N}}{{\widetilde{\text { wagebill }_{r j}}}^{P}}=\frac{\widetilde{\text { wagebill }}_{s j}^{N}}{\widetilde{\text { wagebill }}_{s j}^{P}}
$$

Under the alternative hypothesis that quality-adjusted relative wages differ across regions by a proportion $\gamma_{r s} \neq 1$, observed relative wages vary because of both unobserved differences in factor quality and differences in 
quality-adjusted relative wages. Relative unit factor input requirements also typically vary and we obtain the prediction that, under the alternative hypothesis, observed relative wage bills generally differ across regions:

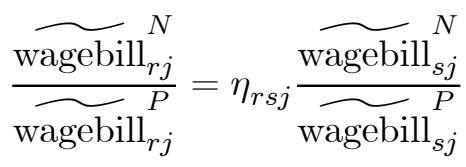

where $\eta_{r s j}$ is a function of the difference in quality-adjusted relative wages $\left(\gamma_{r s}\right)$ and the difference in unit factor input requirements.

Unobserved variation in factor quality means that one cannot determine the existence and magnitude of relative wage differences from an analysis of wage data alone. However, by exploiting information on the relative wage bills of skilled and unskilled workers, one can control for unobserved factor quality. Finding that $\eta_{r s j} \neq 1$ is sufficient to reject the null hypothesis that quality-adjusted relative wages are equalized across regions.

\subsection{Relative Wages Across Regions}

Normalizing the wage bill of skilled workers relative to unskilled workers in all regions $r$ by the relative wage bill in a base region $s$ and taking logs, one obtains the following empirical specification:

$$
\ln \left(\frac{R W B_{r j}}{R W B_{s j}}\right)=\sum_{r} \alpha_{r}^{s} d_{r}+\varepsilon_{r s j}
$$

where $R W B=$ wagebill $^{N} /$ wagebill $^{P} ; d_{r}$ are a set of region dummies; $\alpha_{r}^{s}$ are the coefficients on the region dummies where $s$ is the base region; and $\varepsilon_{r s j}$ is a stochastic error.

Finding that the coefficients on the region dummies are jointly statistically significantly different from zero is sufficient to reject the null hypothesis. Under the assumption that the production technology takes the constant elasticity of substitution (CES) form with elasticity $\sigma_{j}=$ $1 /\left(1-\rho_{j}\right)$, the differences in relative wage bills across regions in equation (4) can be written as an explicit function of $\gamma_{r s}$ and the CES parameter $\rho_{j}: \eta_{r s j}=\left(\gamma_{r s}\right)^{\rho_{j} /\left(\rho_{j}-1\right)}$. Assuming that the elasticity of substitution is the same across industries, and choosing a value for this elasticity, one may extract from the estimated coefficients on the regional dummies 
the estimated unobserved differences in quality-adjusted relative wages: $\alpha_{r}^{s}=\ln \left(\left(\gamma_{r s}\right)^{\rho /(\rho-1)}\right)$.

Existing estimates of the elasticity of substitution between skilled and unskilled workers in the labor literature (see, in particular Katz and Autor 1999 and Katz and Murphy 1992) suggest a value of $\sigma>1$, which corresponds to $0<\rho<1$. Hence, a positive estimated value of the coefficient on the regional dummies, $\alpha_{r}^{s}=\ln \left(\left(\gamma_{r s}\right)^{\rho /(\rho-1)}\right)$, corresponds to a lower relative wage of skilled workers in region $r$ than in the base region $s\left(\gamma_{r s}<1\right)$.

This approach thus provides a method for testing for relative wage bill differences and estimating their magnitude that is robust to unobserved variation in factor quality. Bernard et. al. (2003) demonstrate how the methodology reviewed here is consistent with very general production environments, including imperfect competition, increasing returns to scale, and differences in factor composition as well as quality.

\subsection{Data Description}

To test for differences in relative wages across regions and their implications for industrial structure we need information on employment and wages by industry and region over a long time interval. We use data from the Annual Respondents Database (ARD) sample of manufacturing establishments from 1976 to $1993 .{ }^{5}$ We supplement this data with the more limited information available for the population of manufacturing plants for the period 1980 to $1993 .{ }^{6}$ Each establishment and plant can be associated with one of 209 four-digit U.K. 1980 Standard Industrial Classification (SIC) industries and can be located in one of 10 broad Administrative Regions and one of 63 more finely detailed Counties and Scottish Regions enumerated in Table 1. Following standard practice, we measure skilled

\footnotetext{
${ }^{5}$ ARD establishments correspond roughly to a 'line of business.' The ARD sample includes the population of larger establishments and a sample of smaller establishments (typically, those with less than 100 employees). We explored controlling for the existence of only a sample of smaller establishments in a variety of ways (eg weighting observations by sampling probabilities, estimating for the population of larger establishments only). None of these experiments changed the qualitiative pattern of results. For further discussion of the ARD data, see for example Griffith (1999).

${ }^{6}$ At the plant-level, only information on employment, industry, location and ownership is reported. 1980 is the first year where both county of location and employment are available for plants.
} 
and unskilled by non-production and production workers respectively. A key advantage of our methodology is that it explicitly controls for unobserved region-industry variation in the quality and composition of these worker categories.

We construct industry-region measures of total payments to each type of worker as well as total employment. To abstract from high frequency timeseries fluctuations, we average the annual data over three-year time periods. Finally, we exclude all industries classified as 'other manufacturing' since these are explicitly heterogeneous categories and may include different subindustries in different regions. This leaves 185 industries in the sample.

\subsection{Baseline Relative Wage Bill Estimates}

We begin by estimating quality-adjusted relative wage differences across U.K. regions using the relative wage bill specification in equation (5). In our baseline results, we choose the U.K. as a whole as the base region, excluding the own region from the definition of the U.K. as a whole.

Table 2 presents estimation results for Administrative Regions during the six three-year time periods from 1976 to 1993. We observe a consistent pattern of results over time. There is typically one rejection above zero at conventional levels of statistical significance (the South-East of England) and four rejections below zero (Yorkshire and Humberside, Northern, Wales and Scotland). An exception is 1988-90, a period of recession, when the two Midlands regions and the North-West also reject below zero. ${ }^{7}$

Figure 2 displays the evolution of the estimated coefficients on the regional dummies over time. Three aspects of the results stand out. First, the gap between the relative skilled wage bill in the South-East and the U.K. as a whole grows steadily larger over time. Second, the negative impact of the 1988-90 recession on the Midlands regions and the North-West is again apparent. Finally, the relative skilled wage bill in the Northern Region (the North East) falls gradually relative to the U.K. as a whole from the late 1970s to mid-1980s.

As discussed above, for plausible values of the elasticity of substitution between skilled and unskilled workers, a positive estimated coefficient on

\footnotetext{
${ }^{7}$ This suggests that unskilled worker wages fell relative to the UK in these regions during the recession.
} 
the regional dummies corresponds to a relative wage of skilled workers lower than in the base region. Thus, the quality-adjusted relative wage of skilled workers in the South-East has fallen over time, while the relative wage of skilled workers in the Northern region rose from the late 1970s to mid-1980s.

Table 3 summarizes estimation results for counties, where we again observe a systematic pattern across time periods. Positive and statistically significant coefficients on the regional dummies are concentrated in the South East, with some evidence of this low relative skilled wage cone spreading out over time, as Wiltshire joins the South-Eastern counties from 1985 to 1987 onwards. Negative and statistically significant coefficients on the regional dummies are disproportionately concentrated outside of the South East in the North and West of the United Kingdom (in the Northern, Scotland and Wales Administrative Regions). Figure 3 shows the geographic pattern of estimated coefficients for the initial period.

Equation (5) may also be estimated using a particular region, rather than the U.K. as a whole, as the base region $s$. Table 4 summarizes the results of estimating equation (5) when all regions are used as the base region. Approximately $50 \%$ of bilateral Administrative Region pairs reject the equalization of relative factor prices at the $10 \%$ level, while $25 \%$ of bilateral county pairs reject at this level of statistical significance.

The rejection of relative factor price equalization is not driven by the South East alone - across all time periods in Table 4, each Administrative Region rejects with an average of six other regions and a minimum of two. Table 5 examines the number of bilateral rejections by base region, where we again observe a systematic pattern across time periods, with the South East and Northern regions producing the highest number of rejections.

The results in this section show that skill premia are lower in the part of the U.K. that is relatively well-endowed with skilled workers, i.e. the South East. This finding is consistent with a multi-cone Heckscher-Ohlin view of the U.K. Our results are hard to reconcile with multiple factor models from the new economic geography literature which would predict higher relative wages for skilled workers in skill-abundant areas. We turn now to the predictions of the model on the relationship between industrial structure and relative wages. 


\subsection{Relative Wages and Production Structure}

Having estimated significant differences in relative wages differences across regions, we now examine whether this variation is systematically related to production structure by regressing:

$$
Z_{r s}=\beta_{0}+\beta_{1}\left|\hat{\alpha}_{r}^{s}\right|+\beta_{2} I_{r}+\beta_{3} I_{s}+u_{r s}
$$

where $Z_{r s}$ is a measure of the similarity in industrial structure of regions $r$ and $s$, discussed further below; $\hat{\alpha}_{r}^{s}$ are the estimated bilateral relative wage bill differences from equation (5); and $u_{r s}$ is a stochastic error. ${ }^{8}$ We include as controls the total number of industries produced by region $r$ and $s, I_{r}$ and $I_{s}$, to capture the idea that, other things equal, two regions which each produce in a large number of industries are likely to have more industries in common.

\subsection{Bilateral Wage Bill Differences and Production Overlap}

Table 6 investigates whether the magnitude of the estimated differences in relative wage bills (capturing differences in quality-adjusted relative wages) is systematically related to industrial structure in line with the predictions of general equilibrium trade theory. In view of the small number of Administrative Regions, we concentrate on the estimation results using counties.

Equation (6) is estimated using two alternative measures of regions' similarity in terms of industrial structure. The first is a measure of industry overlap that is based on the number of industries that are present in both regions. By looking at whether or not an industry exists at all within each region, we focus on the theoretically consistent idea of complete specialization. This measure, $I_{r s}$, is a count of the number of industries common to both region $r$ and region $s$. In the notation of equation (6), $Z_{r s}=I_{r s}$. Similarity of industrial structure across regions is increasing in this measure.

The second measure of industrial similarity exploits information not just on whether an industry exists in each region but also on its level of economic activity. This measure is widely used in the empirical geography

\footnotetext{
${ }^{8}$ The econometric estimates so far have only exploited information on industries that exist in both regions $r$ and $s$.
} 
literature (see, in particular, Krugman 1991), and is the sum of the absolute differences in industry shares of manufacturing employment in the two regions, so $Z_{r s}=\sum_{j} a b s\left(\frac{L_{r j}}{L_{r}}-\frac{L_{s j}}{L_{s}}\right)$. The industry share measure takes the value zero if regions $r$ and $s$ have exactly the same industrial structure and attains a maximum value of 2 when the regions' employment structures are such that they have no industries at all in common. Similarity of industrial structure across regions is decreasing in this measure. In calculating both measures of industrial similarity we make use of the population data from the ARD from 1980 to 1993, again taking averages over three year periods, (two years for the initial period).

We pool the cross-sections of industrial similarity measures and estimated relative wage bill differences over time, including a full set of time dummies to control for macroeconomic shocks and abstract from secular trends in the two variables. Columns (1) and (3) of Table 6 present our baseline estimates of equation (6) for the two measures of industrial similarity.

Using industry overlap as the dependent variable, we find a negative and statistically significant coefficient on the estimated relative wage bill differences. This result is consistent with the hypothesis that regions with bigger differences in relative wages for skilled and unskilled workers share fewer industries. Using the industry share measure, we obtain a positive and statistically significant coefficient, again as predicted by the theory. Region pairs with greater differences in relative wages are indeed less similar in terms of industrial structure.

In Columns (2) and (4) we include region-pair dummies so that the relationship between industrial similarity and relative wages is identified solely from the time-series variation in the data. Again as predicted by the theory, we find that regions that experienced diverging relative wages became less similar in terms of industrial structure.

This section has provided strong evidence in favor of the hypothesis that regional industrial structure in the United Kingdom is consistent with a multiple cone general equilibrium trade model. Relative wages are significantly different across regions, with lower relative skilled wages in regions with more skilled workers. In addition, regions with disparate relative wages have disparate industrial structures, with fewer industries in common and less similar industry shares. In the next section, we consider 
whether industries have responded to these differences in terms of their geographic location and use of factors.

\section{Changing Industrial Structure and Initial Wage Differences}

\subsection{Between and Within Industry Responses}

The results from the previous section suggest that regional relative wage differences have persisted, i.e. that they have not been unwound by labor migration or industrial relocation. In this section, we ask whether industries have responded to the observed relative wage differences over long horizons. ${ }^{9}$ Other things equal, we would expect regions with lower initial relative wages of skilled workers to experience greater increases in the share of skill-intensive industries in employment as firms choose to match their factor needs with advantageous relative factor prices. This hypothesis relates to between-industry changes in employment shares over time, which we examine with the following empirical specification:

$$
\Delta_{0, T}\left(\frac{L^{N}}{L}\right)_{r}=\delta_{0}+\delta_{1} \hat{\alpha}_{r 0}^{U K}+\delta_{2}\left(\frac{L^{N}}{L}\right)_{r 0}+\omega_{r}
$$

where $\Delta$ is the difference operator; $T$ is the length of period over which the difference is taken; $L^{N}$ denotes employment in skill-intensive industries, defined as those with an average wage bill of non-production workers relative to production workers in the top one third of the distribution; $L$ denotes employment; and $\hat{\alpha}_{r 0}^{U K}$ are the initial period estimates of relative wage bill differences with the U.K. as a whole taken as the base region.

The initial share of employment in skill-intensive industries is included as a control in the regression to allow for mean reversion and convergence effects. Since a positive estimated value of the coefficient $\hat{\alpha}_{r 0}^{U K}$ corresponds to a relative wage of skilled workers in region $r$ lower than in the U.K. as a whole, theory leads us to expect a positive and statistically significant value of $\delta_{1}$.

Besides changes in the composition of industries, we might also expect changes in the factor usage within industries across regions. Firms located in regions with lower relative wages of skilled workers may increase

\footnotetext{
${ }^{9}$ We recognize that sunk costs of relocation may prevent firms and industries from adjusting in the short run so we use the longest horizon available in our data.
} 
the intensity with which they use skilled workers by more than the same industry located in regions where skilled wages are relatively high. This hypothesis relates to within-industry changes in skill-intensity over time, which we examine using the following regression:

$$
\Delta_{0, T}\left(\frac{\text { wagebill }_{r j}^{N}}{\text { wagebill }_{r j}^{P}}\right)=\eta_{j}+\lambda_{1} \hat{\alpha}_{r 0}^{U K}+\nu_{r j}
$$

where $\eta_{j}$ is an industry fixed effect and $\hat{\alpha}_{r 0}^{U K}$ are again the initial period estimates of relative wage bill differences with the U.K. as a whole taken as the base region. Since a positive estimated value of the coefficient $\hat{\alpha}_{r 0}^{U K}$ corresponds to a lower relative wage of skilled workers in region $r$, theory also leads us to expect a positive and statistically significant value of $\lambda_{1}$.

\subsection{Empirical Results}

First, we examine changes in industrial structure between skill-scarce and skill-intensive industries. Estimates of equation (7) are reported in Table 7 where we include the initial employment share of skill-intensive industries to control for mean reversion and convergence effects. As predicted by theory, we find a positive and significant relationship. Counties with the lowest initial relative wages of skilled workers (the highest estimated difference in relative wage bills) experience the greatest increases in the share of skill-intensive industries in employment after controlling for the share of skill-intensive industries in the initial period.

Second, we examine whether within industries, we observe factor intensity systematically responding to variation in the relative wage of skilled workers. Table 8 reports the results of estimating equation (8), regressing the change in the region-industry relative wage bill of skilled workers on the initial estimated difference in relative wage bills. Our preferred specification in Column (2) includes industry dummies, so that we identify from within-industry variation across regions. We find that industries in regions with the lowest initial relative wages of skilled workers experience the greatest increases in the ratio of the skilled to unskilled wage bill. These changes can be interpreted as product mix adjustments. In response to persistent low skill premia, firms may choose to reallocate production away from labor-intensive goods and towards skill-intensive goods within 
industries. This disaggregate change parallels the industry reallocation highlighted in Table 7.

The results from this section provide additional evidence of the importance of relative wages in shaping industrial structure across regions within the U.K.. Initial differences in relative skilled wages are associated with subsequent changes in the composition of industries and in their use of inputs. Regions with low relative wages for skilled labor see employment increases in skill-intensive industries and an increased use of skill within industries.

\section{Conclusions}

We present evidence of a strong relationship between regional production structure and relative wages. Using finely detailed industry and region data, we report statistically significant and economically large relative wage differences across regions within the United Kingdom. In accordance with the predictions of general equilibrium trade theory, we demonstrate that pairs of regions with larger estimated differences in relative wages are less similar in industrial structure.

We also find that both industry location and industry skill intensity respond systematically to persistent relative wage differences over time. Regions with lower skill premia experienced greater increases in the share of skill-intensive industries in employment and larger rises in the intensity with which skilled workers are used within industries. These dynamic responses suggest firms reallocate production of skill-intensive industries and products towards regions whose relative factor prices best match their factor needs.

Our findings emphasize the way in which industrial structure and relative wages are jointly and endogenously determined in general equilibrium. The analysis has a number of implications for the recent policy debate about regional variation in economic performance within the United Kingdom. One interpretation of our results is that industries move towards workers more readily than workers move towards industries. As a result, regional development assistance designed to introduce new, skill-intensive industries to faltering, skill-scarce regions may be less successful than policies designed to boost skill-scarce regions' skilled labor pools. Regional 
policies intended to promote industry relocation must take into account how closely industry factor intensities and region endowments match.

Variation in industrial composition across regions also implies asymmetric exposure to common external shocks. For example, workers in regions specializing in low-skill industries will be more adversely affected by declines in the price of unskilled goods on world markets than workers in regions where these goods are not produced (who simply enjoy a terms of trade gain). Evidence of asymmetry within the U.K. relates to a broader debate about the impact of the European Monetary Union and the extent to which individual regions within a country are more similar than regions across countries. 


\section{References}

Bernard, A. B. and Schott, P. K. (2003) 'Factor Price Equality and the Economies of the United States', Tuck School of Business and Yale School of Management, revised version of NBER Working Paper, 8068, available from, http://mba.tuck.dartmouth.edu/pages/faculty/andrew.bernard/.

Bernard, A. B., Redding, S., Schott, P.K. and Simpson, H. (2003) 'Factor Price Equalization in the U.K.?: A General Test and Evidence', revised version of NBER Working Paper, 9052, available from http://mba.tuck.dartmouth.edu/pages/faculty/andrew.bernard/.

Cabinet Office (1999) Sharing the Nation's Prosperity: Variations in Economic and Social Conditions Across the U.K., Report to the Prime Minister, London.

Cameron, C and Muellbauer, J (2000) 'Earnings Biases in the U.K. Regional Accounts: Some Economic Policy and Research Implications', Economic Journal, vol. 110, no. 464, pp. F412-F429

Cameron, C and Muellbauer, J (2001) 'Earnings, Unemployment, and Housing in Britain', Journal of Applied Econometrics, vol. 16, 3, pp. 203-220.

Duranton, G and Monastiriotis, V (2002) 'Mind the Gaps: The Evolution of Regional Earnings Inequalities in the U.K.', Journal of Regional Science, vol. 42, no. 2, May, pp. 219-56.

Griffith, R (1999) 'Using the ARD Establishment-level Data to Look at Foreign Ownership and Productivity in the United Kingdom', Economic Journal, 109, F416-F442.

HM Treasury and DTI (2001) 'Productivity in the U.K.: 3 - The Regional Dimension', London. http://www.hmtreasury.gov.uk/mediastore/otherfiles/REGIONAL_POLICY.pdf

Jackman, R and Savouri, S (1992) 'Regional Migration in Britain: An Analysis of Gross Flows Using NHS Central Register Data', Economic Journal, 102, 1433-50. 
Katz, L and Autor, D (1999) 'Changes in the Wage Structure and Earnings Inequality', in (eds) Ashenfelter, O and Card, D, Handbook of Labor Economics, Vol 3A, North-Holland, 1463-1555.

Katz, L and Murphy, K (1992) 'Changes in Relative Wages, 1963-1987: Supply and Demand Factors', Quarterly Journal of Economics, 107(1), 35-78.

Krugman, P (1991) Geography and Trade, MIT Press, Cambridge, MA.

Leamer, Edward E. (1987) 'Paths of Development in the Three-Factor, n-Good General Equilibrium Model', Journal of Political Economy 95,961-999.

Leontief, W (1953) 'Domestic Production and Foreign Trade: The American Capital Position Re-examined', Proceedings of the American Philosophical Society, 97, 332-49.

Lerner, A (1952) 'Factor Prices and International Trade', Economica, 19(1), $1-15$.

Trefler, D (1993) 'International Factor Price Differences: Leontief was Right!', Journal of Political Economy, 101(6), 961-87.

Venables, A and Rice, P (2003) 'Equilibrium Regional Disparities: Theory and U.K. Evidence', Regional Studies, forthcoming. 


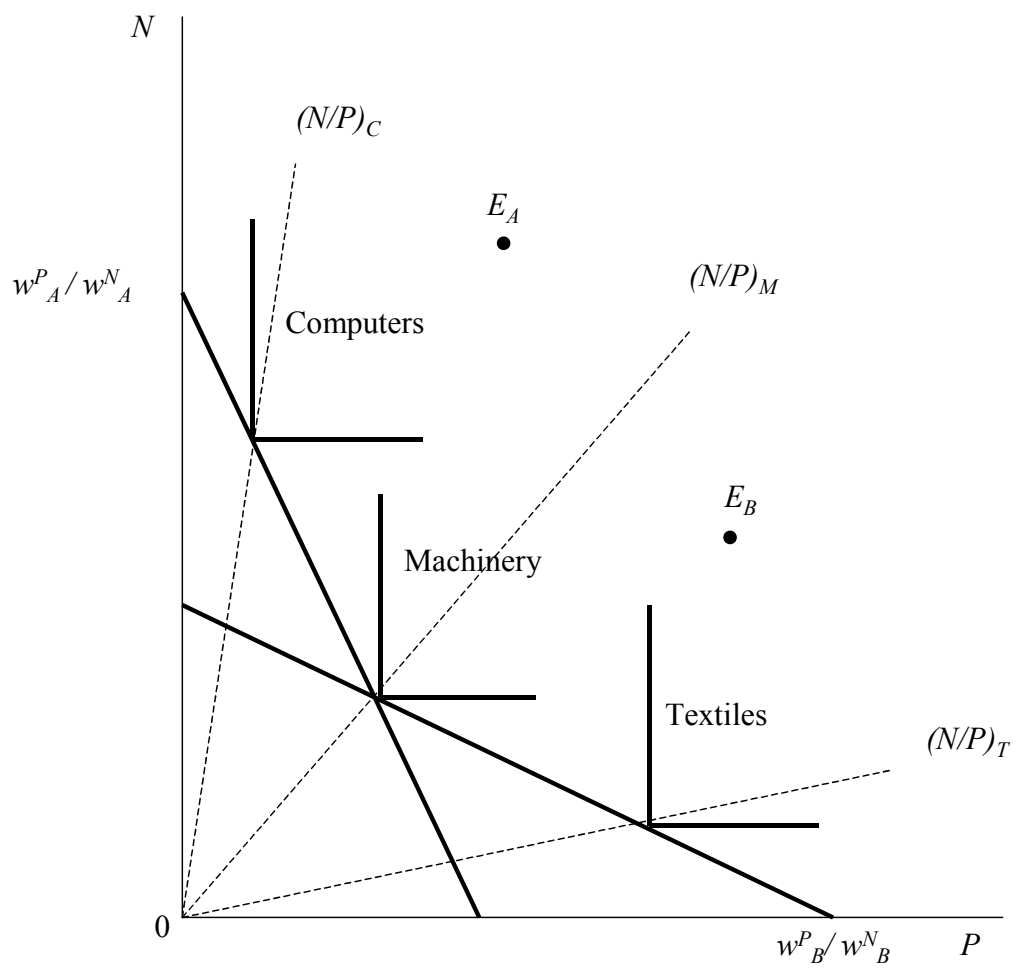

Figure 1: Multiple Cones of Diversification 


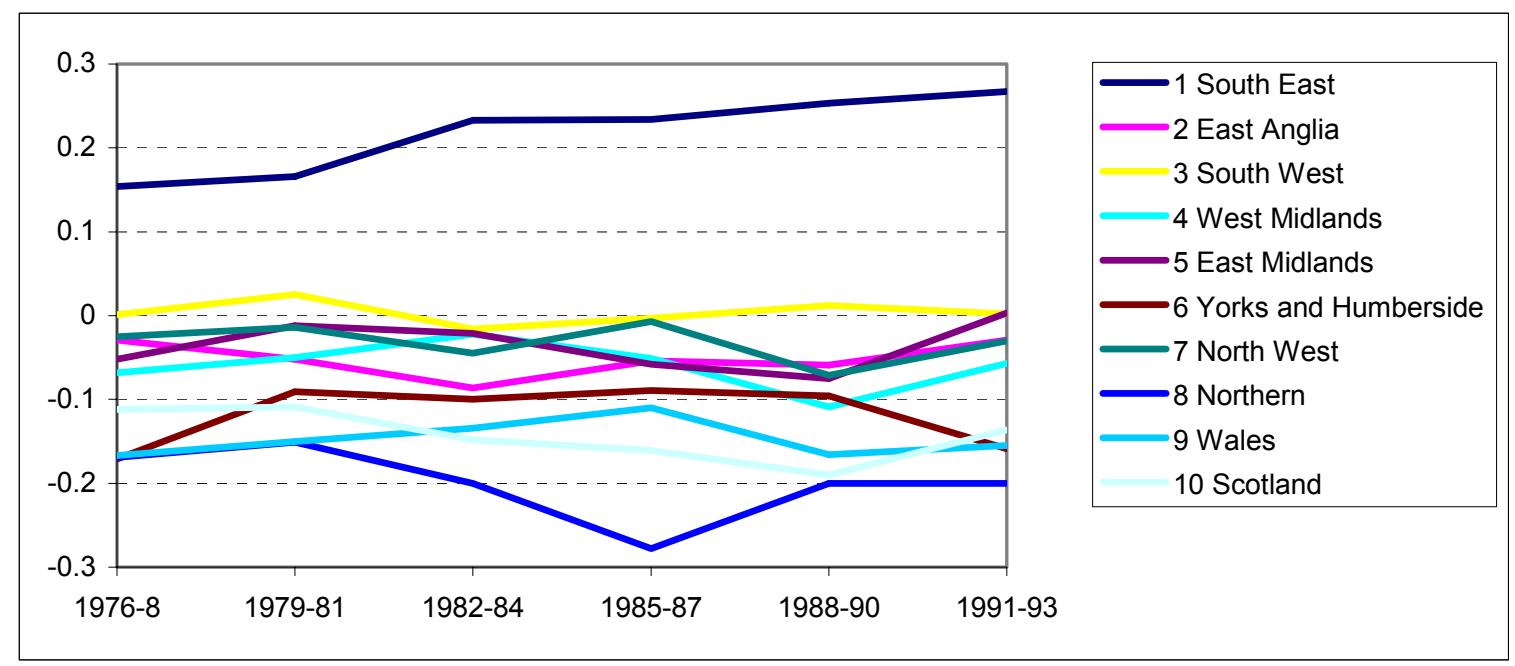

Figure 2: Estimated Coefficients over Time, Administrative Regions, UK Base 


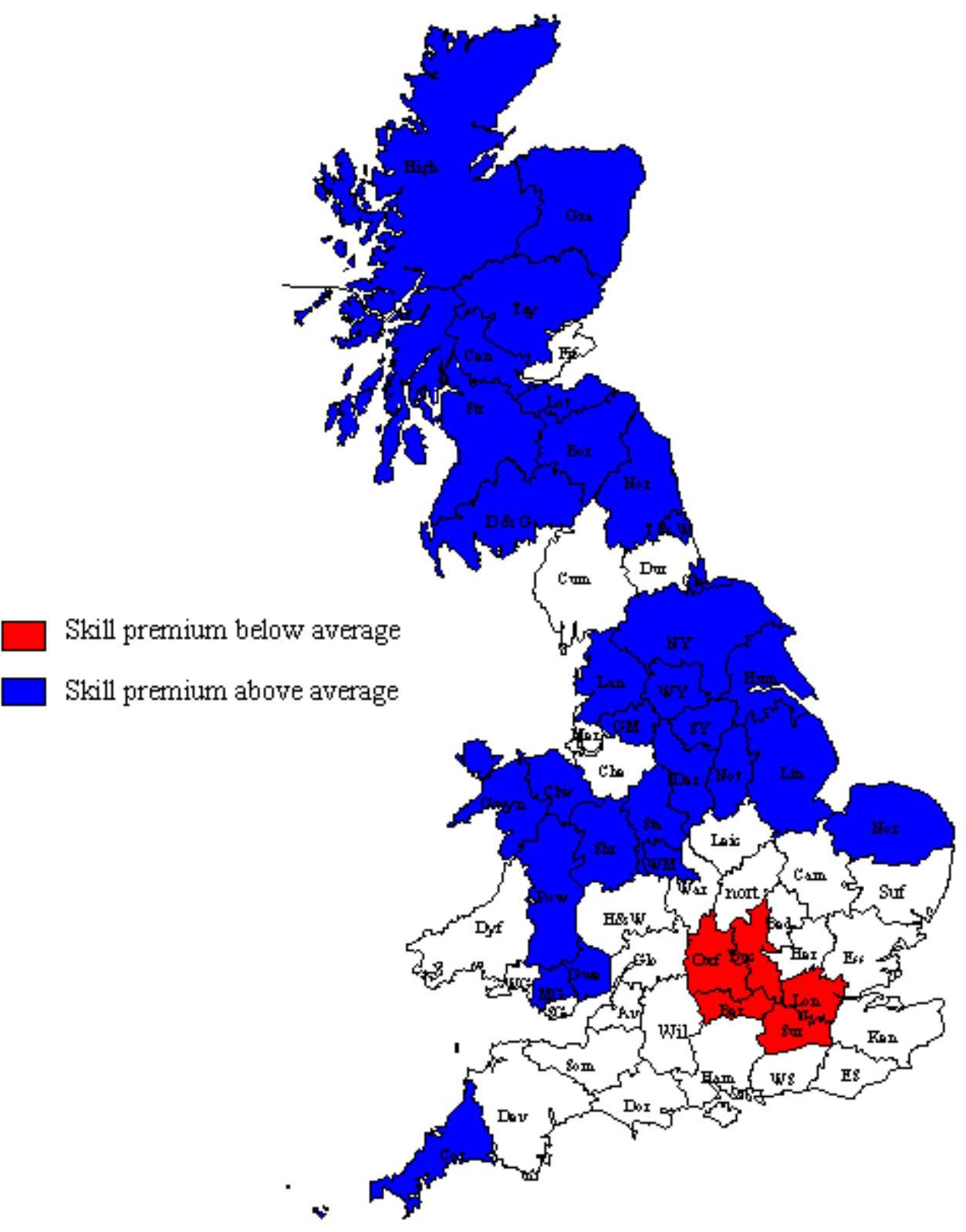

Figure 3: Counties with positive (skill premium below average) and negative (skill premium above average) coefficients (1976-78) 


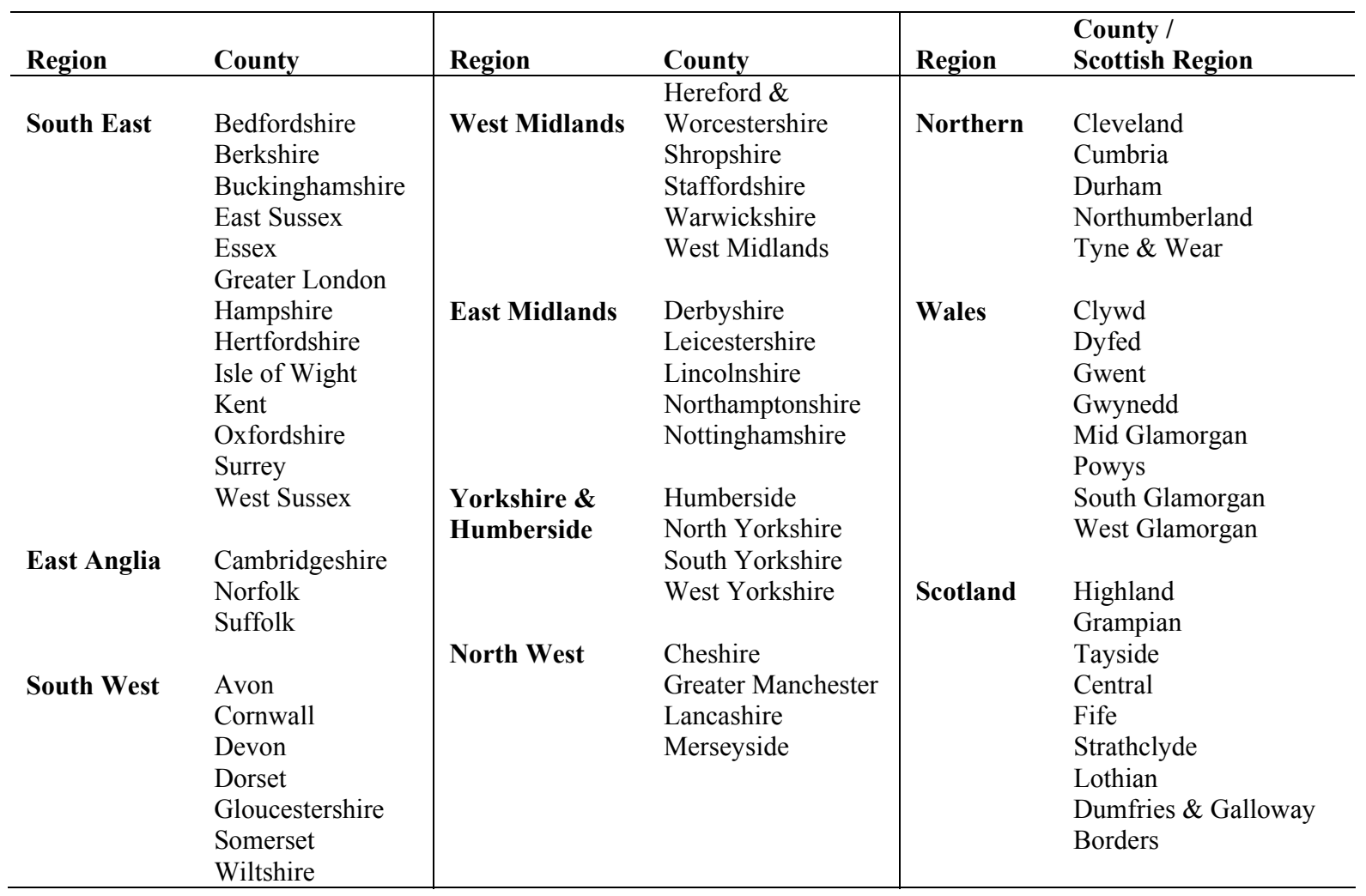

Table 1: Administrative Regions, Counties and Scottish Regions 


\begin{tabular}{l|llllll}
\hline Administrative & $1976-78$ & $1979-81$ & $1982-84$ & $1985-87$ & $1988-90$ & $1991-93$ \\
Region & \multicolumn{7}{|c}{} & & & \\
\hline South East & $0.154^{* * *}$ & $0.166^{* * *}$ & $0.233 * * *$ & $0.234^{* * *}$ & $0.253^{* * *}$ & $0.267^{* * *}$ \\
East Anglia & -0.029 & -0.052 & $-0.086^{* *}$ & -0.054 & -0.059 & -0.029 \\
South West & 0.001 & 0.025 & -0.016 & -0.003 & 0.012 & 0.002 \\
West Midlands & $-0.068^{*}$ & -0.050 & -0.022 & -0.051 & $-0.109^{* * *}$ & -0.057 \\
East Midlands & -0.052 & -0.012 & -0.021 & -0.058 & $-0.075^{*}$ & 0.003 \\
Yorks \& Humberside & $-0.171^{* * *}$ & $-0.091^{* *}$ & $-0.100^{* * *}$ & $-0.089 * *$ & $-0.096^{* *}$ & $-0.159^{* * *}$ \\
North West & -0.025 & -0.014 & -0.045 & -0.007 & $-0.071^{*}$ & -0.030 \\
Northern & $-0.169^{* * *}$ & $-0.151^{* * *}$ & $-0.200^{* * *}$ & $-0.278^{* * *}$ & $-0.200^{* * *}$ & $-0.200^{* * *}$ \\
Wales & $-0.167 * * *$ & $-0.150^{* * *}$ & $-0.134^{* * *}$ & $-0.110^{* * *}$ & $-0.166^{* * *}$ & $-0.155^{* * *}$ \\
Scotland & $-0.112^{* * *}$ & $-0.109^{* * *}$ & $-0.148^{* * *}$ & $-0.161^{* * *}$ & $-0.190^{* * *}$ & $-0.136^{* * *}$ \\
\hline F-stat (p-value) & 0.000 & 0.000 & 0.000 & 0.000 & 0.000 & 0.000 \\
Observations & 1,584 & 1,544 & 1,564 & 1,541 & 1,581 & 1,580 \\
\hline
\end{tabular}

*** significant at $1 \%$ level, $* *$ significant at $5 \%$ level, * significant at $10 \%$ level. Authors' calculation using the ARD (Source ONS).

Table 2: Tests of Common Relative Wage Across Administrative Regions, UK Base 


\begin{tabular}{|c|c|c|c|c|c|c|}
\hline & $1976-78$ & 1979-81 & $1982-84$ & $1985-87$ & $1988-90$ & 1991-93 \\
\hline \multicolumn{7}{|l|}{ Positive } \\
\hline South East & $\begin{array}{l}\text { Berkshire } \\
\text { Buckinghamshire } \\
\text { Oxfordshire } \\
\text { Surrey } \\
\text { Greater London }\end{array}$ & $\begin{array}{l}\text { Berkshire } \\
\text { Surrey } \\
\text { West Sussex } \\
\text { Greater London }\end{array}$ & $\begin{array}{l}\text { Berkshire } \\
\text { Hampshire } \\
\text { Surrey } \\
\text { Greater London }\end{array}$ & $\begin{array}{l}\text { Berkshire } \\
\text { Buckinghamshire } \\
\text { Surrey } \\
\text { Greater London }\end{array}$ & $\begin{array}{l}\text { Berkshire } \\
\text { Hampshire } \\
\text { Surrey } \\
\text { West Sussex } \\
\text { Greater London }\end{array}$ & $\begin{array}{l}\text { Essex } \\
\text { Hampshire } \\
\text { Surrey } \\
\text { West Sussex } \\
\text { Greater London }\end{array}$ \\
\hline South West & & & & Wiltshire & Wiltshire & Wiltshire \\
\hline East Midlands & & & & & & Leicestershire \\
\hline North West & & Cheshire & & Cheshire & & \\
\hline \multicolumn{7}{|l|}{ Negative } \\
\hline South East & & East Sussex & Bedfordshire & Isle Of Wight & East Sussex & \\
\hline$\overline{\text { East Anglia }}$ & Norfolk & $\begin{array}{l}\text { Norfolk } \\
\text { Suffolk }\end{array}$ & $\begin{array}{l}\text { Norfolk } \\
\text { Suffolk }\end{array}$ & Suffolk & $\begin{array}{l}\text { Norfolk } \\
\text { Suffolk }\end{array}$ & \\
\hline South West & Cornwall & $\begin{array}{l}\text { Cornwall } \\
\text { Devon }\end{array}$ & $\begin{array}{l}\text { Avon } \\
\text { Cornwall } \\
\text { Dorset }\end{array}$ & $\begin{array}{l}\text { Cornwall } \\
\text { Somerset }\end{array}$ & $\begin{array}{l}\text { Cornwall } \\
\text { Devon }\end{array}$ & $\begin{array}{l}\text { Cornwall } \\
\text { Devon }\end{array}$ \\
\hline $\begin{array}{l}\text { West } \\
\text { Midlands }\end{array}$ & \begin{tabular}{|l} 
Shropshire \\
Staffordshire \\
West Midlands
\end{tabular} & West Midlands & West Midlands & Shropshire & $\begin{array}{l}\text { Shropshire } \\
\text { Staffordshire }\end{array}$ & $\begin{array}{l}\text { Shropshire } \\
\text { Staffordshire }\end{array}$ \\
\hline $\begin{array}{l}\text { East } \\
\text { Midlands }\end{array}$ & \begin{tabular}{|l} 
Derbyshire \\
Lincolnshire \\
Nottinghamshire
\end{tabular} & & $\begin{array}{l}\text { Derbyshire } \\
\text { Lincolnshire } \\
\text { Nottinghamshire }\end{array}$ & $\begin{array}{l}\text { Derbyshire } \\
\text { Nottinghamshire }\end{array}$ & $\begin{array}{l}\text { Derbyshire } \\
\text { Lincolnshire } \\
\text { Nottinghamshire }\end{array}$ & $\begin{array}{l}\text { Lincolnshire } \\
\text { Nottinghamshire }\end{array}$ \\
\hline $\begin{array}{l}\text { Yorkshire } \\
\& \\
\text { Humberside }\end{array}$ & \begin{tabular}{|l} 
Humberside \\
North Yorkshire \\
South Yorkshire \\
West Yorkshire
\end{tabular} & $\begin{array}{l}\text { Humberside } \\
\text { North Yorkshire } \\
\text { West Yorkshire }\end{array}$ & $\begin{array}{l}\text { Humberside } \\
\text { South Yorkshire } \\
\text { West Yorkshire }\end{array}$ & $\begin{array}{l}\text { Humberside } \\
\text { South Yorkshire } \\
\text { West Yorkshire }\end{array}$ & $\begin{array}{l}\text { Humberside } \\
\text { South Yorkshire } \\
\text { West Yorkshire }\end{array}$ & $\begin{array}{l}\text { Humberside } \\
\text { South Yorkshire }\end{array}$ \\
\hline $\begin{array}{l}\text { North } \\
\text { West }\end{array}$ & $\begin{array}{l}\text { Lancashire } \\
\text { Greater Manchester }\end{array}$ & Lancashire & Lancashire & Lancashire & $\begin{array}{l}\text { Lancashire } \\
\text { Greater Manchester } \\
\text { Merseyside }\end{array}$ & \\
\hline Northern & $\begin{array}{l}\text { Cleveland } \\
\text { Northumberland } \\
\text { Tyne \& Wear }\end{array}$ & $\begin{array}{l}\text { Cleveland } \\
\text { Cumbria } \\
\text { Durham } \\
\text { Northumberland } \\
\text { Tyne \& Wear }\end{array}$ & $\begin{array}{l}\text { Cleveland } \\
\text { Cumbria } \\
\text { Durham } \\
\text { Northumberland } \\
\text { Tyne \& Wear }\end{array}$ & $\begin{array}{l}\text { Cleveland } \\
\text { Cumbria } \\
\text { Durham } \\
\text { Northumberland } \\
\text { Tyne \& Wear }\end{array}$ & $\begin{array}{l}\text { Cleveland } \\
\text { Durham } \\
\text { Northumberland }\end{array}$ & $\begin{array}{l}\text { Cleveland } \\
\text { Durham } \\
\text { Northumberland }\end{array}$ \\
\hline Wales & \begin{tabular}{|l} 
Clwyd \\
Gwent \\
Gwynedd \\
Mid Glamorgan \\
Powys
\end{tabular} & $\begin{array}{l}\text { Clwyd } \\
\text { Gwent } \\
\text { Gwynedd } \\
\text { Mid Glamorgan } \\
\text { Powys }\end{array}$ & $\begin{array}{l}\text { Clwyd } \\
\text { Gwynedd } \\
\text { Mid Glamorgan } \\
\text { Powys }\end{array}$ & $\begin{array}{l}\text { Clwyd } \\
\text { Gwent } \\
\text { Mid Glamorgan } \\
\text { South Glamorgan } \\
\text { West Glamorgan }\end{array}$ & $\begin{array}{l}\text { Clwyd } \\
\text { Dyfed } \\
\text { Gwynedd } \\
\text { Mid Glamorgan } \\
\text { Powys } \\
\text { South Glamorgan } \\
\text { West Glamorgan }\end{array}$ & $\begin{array}{l}\text { Clwyd } \\
\text { Dyfed } \\
\text { Gwynedd } \\
\text { Mid Glamorgan } \\
\text { Powys } \\
\text { West Glamorgan }\end{array}$ \\
\hline Scotland & $\begin{array}{l}\text { Borders } \\
\text { Central } \\
\text { Dumfries \& } \\
\text { Galloway } \\
\text { Grampian } \\
\text { Highland } \\
\text { Lothian } \\
\text { Strathclyde } \\
\text { Tayside }\end{array}$ & $\begin{array}{l}\text { Borders } \\
\text { Central } \\
\text { Dumfries \& } \\
\text { Galloway } \\
\text { Fife } \\
\text { Grampian } \\
\text { Highland } \\
\text { Strathclyde } \\
\text { Tayside }\end{array}$ & $\begin{array}{l}\text { Borders } \\
\text { Central } \\
\text { Dumfries \& } \\
\text { Galloway } \\
\text { Fife } \\
\text { Grampian } \\
\text { Highland } \\
\text { Lothian } \\
\text { Strathclyde } \\
\text { Tayside }\end{array}$ & $\begin{array}{l}\text { Central } \\
\text { Dumfries \& } \\
\text { Galloway } \\
\text { Fife } \\
\text { Grampian } \\
\text { Highland } \\
\text { Strathclyde }\end{array}$ & $\begin{array}{l}\text { Borders } \\
\text { Central } \\
\text { Dumfries \& } \\
\text { Galloway } \\
\text { Fife } \\
\text { Grampian } \\
\text { Highland } \\
\text { Strathclyde } \\
\text { Tayside }\end{array}$ & 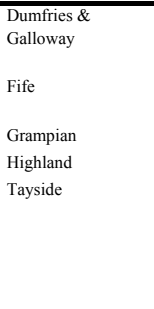 \\
\hline $\begin{array}{l}\text { F-stat } \\
\text { (p-value) } \\
\text { Obs }\end{array}$ & 345 & & $\overline{0}$ & 7 & ,322 & 5,093 \\
\hline
\end{tabular}

Table 3: Counties with positive and negative significant coefficients, UK base 


\begin{tabular}{l|ll|llc}
\hline \multicolumn{2}{l}{ Region definition } & & \multicolumn{3}{l}{$\begin{array}{l}\text { Distribution of rejections across all } \\
\text { base regions at the 10\% level of } \\
\text { significance }\end{array}$} \\
\cline { 3 - 6 } $\begin{array}{l}\text { Administrative } \\
\text { Regions }\end{array}$ & $\begin{array}{l}5 \% \text { significance } \\
\text { level }\end{array}$ & $\begin{array}{l}10 \% \text { significance } \\
\text { level }\end{array}$ & Minimum & Mean & Maximum \\
\hline $1976-78$ & $58 \%$ & $64 \%$ & 3 & 6 & 9 \\
$1979-81$ & $48 \%$ & $57 \%$ & 2 & 6 & 9 \\
$1982-84$ & $54 \%$ & $59 \%$ & 3 & 6 & 9 \\
$1985-87$ & $51 \%$ & $57 \%$ & 2 & 6 & 9 \\
$1988-90$ & $44 \%$ & $56 \%$ & 2 & 6 & 9 \\
$1991-93$ & $36 \%$ & $44 \%$ & 2 & 5 & 9 \\
\hline Counties & & & & & \\
\hline $1976-78$ & $22 \%$ & $30 \%$ & 2 & 25 & 53 \\
$1979-81$ & $15 \%$ & $23 \%$ & 1 & 20 & 41 \\
$1982-84$ & $17 \%$ & $24 \%$ & 3 & 20 & 41 \\
$1985-87$ & $16 \%$ & $24 \%$ & 3 & 20 & 41 \\
$1988-90$ & $20 \%$ & $28 \%$ & 3 & 20 & 41 \\
$1991-93$ & $20 \%$ & $26 \%$ & 4 & & \\
\hline
\end{tabular}

Authors' calculation using the ARD (Source ONS) based on region-industry cells with at least 3 establishments. The number of region-industry cells is higher in 1976-1978 (as are the number of rejections) due to finer sampling of establishments.

Table 4: Bilateral region-pair rejections

\begin{tabular}{l|lllllll}
\hline & $1976-78$ & $1979-81$ & $1982-84$ & $1985-87$ & $1988-90$ & $1991-93$ & Mean \\
\hline South East & 9 & 9 & 9 & 9 & 9 & 9 & 9 \\
East Anglia & 3 & 4 & 3 & 4 & 3 & 2 & 3 \\
South West & 8 & 6 & 5 & 5 & 8 & 5 & 6 \\
West Midlands & 5 & 3 & 4 & 5 & 4 & 3 & 4 \\
East Midlands & 6 & 5 & 5 & 2 & 3 & 4 & 4 \\
Yorks \& Humberside & 6 & 6 & 6 & 5 & 4 & 2 & 5 \\
North West & 5 & 4 & 4 & 6 & 4 & 3 & 4 \\
Northern & 6 & 7 & 7 & 7 & 7 & 6 & 7 \\
Wales & 5 & 2 & 4 & 4 & 2 & 3 & 3 \\
Scotland & 5 & 5 & 6 & 4 & 6 & 3 & 5 \\
\hline Mean & 6 & 6 & 6 & 6 & 6 & 5 & 5 \\
\hline
\end{tabular}

Authors' calculation using the ARD (Source ONS).

Table 5: Bilateral rejections by base region 


\begin{tabular}{l|cc|cc}
\hline Dependent variable $\mathrm{Z}_{\mathrm{rs}}$ & \multicolumn{2}{|c|}{$\mathrm{I}_{\mathrm{rs}}$ (sum industries in common) } & \multicolumn{2}{c}{ Specialisation index } \\
\hline \multirow{3}{*}{$\operatorname{Abs}\left(\hat{\alpha}_{r}^{s}\right)$} & $(1)$ & $(2)$ & $(3)$ & $(4)$ \\
& -1.462 & -0.387 & 0.042 & 0.019 \\
$\mathrm{I}_{\mathrm{r}}$ & $(0.354)$ & $(0.301)$ & $(0.006)$ & $(0.005)$ \\
& 0.591 & 0.545 & -0.002 & -0.002 \\
& $(0.005)$ & $(0.011)$ & $(0.000)$ & $(0.000)$ \\
$\mathrm{I}_{\mathrm{s}}$ & 0.707 & 0.625 & -0.003 & -0.001 \\
& $(0.003)$ & $(0.009)$ & $(0.000)$ & $(0.000)$ \\
\hline Observations & 9,765 & 9,765 & 9,765 & 9,765 \\
Year dummies & Yes & Yes & Yes & Yes \\
Bilateral county pair dummies & No & Yes & No & Yes \\
\hline Robus star
\end{tabular}

Robust standard errors in brackets.

Authors' calculation using the ARD (Source ONS).

Table 6: Industrial specialisation, counties, pooled 3-year cross-sections (1979-81 to $1991-93)$ 


\begin{tabular}{l|cc}
\hline \multicolumn{3}{l}{ Dependent variable $=\%$ point change in share of skill-intensive } \\
industries in county employment $(79-81)$ to $(91-93)$ \\
\hline \multirow{3}{*}{$\hat{\alpha}_{r 0}^{U K}$} & $(1)$ & $(2)$ \\
& 0.050 & 0.202 \\
$\left(\mathrm{~L}^{\mathrm{N}} / \mathrm{L}\right)_{\mathrm{rt}}$ & $(0.061)$ & $(0.080)$ \\
& & -0.284 \\
& & $(0.066)$ \\
Constant & 0.019 & 0.127 \\
& $(0.008)$ & $(0.028)$ \\
\hline Observations & 63 & 63 \\
\hline
\end{tabular}

Robust standard errors in brackets.

Authors' calculation using the ARD (Source ONS).

Table 7: Change in the share of skill-intensive industries and relative wages of skilled workers

\begin{tabular}{l|cc|}
\hline \multicolumn{3}{|c|}{ Dependent variable $=$ change in region-industry relative wagebill (79-81) to (91-93) } \\
\hline \multirow{2}{*}{$\hat{\alpha}_{r 0}^{U K}$} & $(1)$ & $(2)$ \\
& 1.093 & 0.857 \\
Constant & $(0.344)$ & $(0.321)$ \\
& 0.331 & 0.322 \\
& $(0.039)$ & $(0.034)$ \\
\hline Observations & 1,801 & 1,801 \\
4-digit industry dummies & No & Yes \\
\hline
\end{tabular}

Robust standard errors in brackets.

Authors' calculation using the ARD (Source ONS).

Table 8: Change in skill intensity of production and relative wages of skilled workers 